\title{
Private Junior High School Marketing Management to Face the New Students Admission (PPDB) Policies of State Junior High School in Surabaya
}

\author{
Sinta Putri Damayanti ${ }^{1 a^{*}}$, Amrozi Khamidi ${ }^{1, b}$, and Karwanto ${ }^{1, c}$ \\ 1Department of Education Management, Post Graduated, State University of Surabaya, Surabaya, 60213, \\ Indonesia \\ a shintaputri069@gmail.com; b amrozikhamidi@unesa.ac.id; c karwanto@unesa.ac.id \\ *Corresponding Author : shintaputri069@gmail.com | Phone Number: 082232263164
}

\begin{abstract}
This study was conducted to determine the marketing strategy of private schools in facing the new policies of the Surabaya City Office in the Admission of New Junior High School Students. Various internal and external factors also influence the running of the marketing strategy being implemented. This study focuses on: a) marketing strategy including school programs, strategy and gold mix (product, price, location, promotion of human resources, sarpras and service management), b) internal factors including school strengths, school weaknesses and organizational structure, c) factors external includes school opportunities, school threats and political technology, culture. The method used is qualitative research and case study type. The subjects in this study are the principal, the Deputy Principals, especially in the field of public relations who know the relationship between the institution and the wider community, teachers as learning actors, guardians of students as consumers of service users. This research was conducted in the odd semester of the 2019-2020 school year. Data collection techniques using observation, interviews, and documentation. The data analysis technique used in this study was an interactive analysis model consisting of three components, namely data condensation, data triangulation, data presentation and conclusion drawing. The results showed that the marketing strategies implemented by the Labschool Junior High School and Kemala Bhayangkari 1 Surabaya Junior High School were good and maximized by taking advantage of the advantages they had. Inhibiting factors, such as new policies and the number of competitors, can be minimized by continuing to prioritize superior programs and explore existing human resources.
\end{abstract}

Keywords: Strategy; Marketing Management; Educational Services; Student Admission

\section{Introduction}

As the development of technology and information is increasingly rapid, we are entering an era of information transparency that has an impact on the globalization of human life (Tilaar, 2001), many schools are presenting new educational concepts. Various educational policies are also being implemented to improve the education system. Both by local and central government. The existence of policies in education is expected to be able to reduce problems that arise in the world of education itself. In order to realize the goals of education, the government has regulated the management and implementation of education in Government Regulation Number 17 of 2010, which states that the requirements for continuing higher education must go through a student registration process according to their level of education. In addition to Government Regulation Number 17 of 2010, the process of admitting new students is also regulated in the Regulation of the Ministry of Education and Culture Number 14 of 2018 concerning the Admission of New Students for Kindergarten, Elementary Schools, Junior High Schools, Senior High Schools, Vocational High Schools, or other equivalent.

The admission of new students is a selection activity carried out by the education unit for prospective new students to be accepted as new students in the educational unit. Wright and O'neil (2002:23-29) then the process of delivering educational services is the core (core) of all education, quality in all elements that support the educational process is very important to determine the success of the learning process as well as evaluation material for the management of educational institutions and the image formed will form a circle in recruiting customers education. 
Implementation of New Student Admissions (PPDB) in 2018, the Surabaya City Education Office implemented an educational policy regarding the admission of new students at Public Junior High Schools in Surabaya. One of the contents in the policy is about the number of students and the number of study groups at the admission of new students of State Junior High Schools in Surabaya. The content in the policy of the Surabaya City Education Office stipulates that the number of students at the admission of new students for the Junior High School level is at most 38 students (New Student Admissions Policy in Surabaya 2018). This is not in accordance with the Regulation of the Ministry of Education and Culture Number 14 of 2018 where the number of students in 1 study group is 32 students (Nusantara Newspaper, 22 August 2018).

The establishment of policies regarding the number of students and the number of study groups for State Junior High Schools in Surabaya has caused the number of students enrolled in private junior high schools to experience a drastic decline. The number of students enrolled in private junior high schools in Surabaya in 2017/2018 was 18,299 students while in 2018/2019 the number of students enrolled in private junior high schools was 12,215 students. (LPMP Jatim, Editorial August 25 2018).

There are various consequences that arise with this policy. Some of them are that many private junior high schools in Surabaya have a shortage of students. This has an effect on school financial income because almost all sources of private school funding come from parents of students. In order to realize this ideal function, private schools must always orientate themselves so they can survive and able to appear meaningful, amidst the demands for mastery of science and technology and the appreciation of religious values. Therefore madrasas must be more serious in carrying out reforms in school development in a comprehensive and continuous manner and have a future orientation. (Azra, 1999:59)

The private schools that have experienced the impact of this policy are Labschool Unesa Surabaya Junior High School and Kemala Bhayangkari 1 Surabaya Junior High School, this can be seen from the decrease in the number of students enrolling in the Junior High School.

Table 1. Amount of New Students at Labschool Unesa Junior High School and Kemala Bhayangkari 1 Junior High School Surabaya

\begin{tabular}{cccc}
\hline & & \multicolumn{2}{c}{ Amount of Students } \\
\cline { 3 - 4 } Number & Year & Labschool Unesa Junior High School & Kemala Bhayangkari 1 Junior High School Surabaya \\
\hline 1 & $2017 / 2018$ & 56 & 108 \\
\hline 2 & $2018 / 2019$ & 41 & 91 \\
\hline
\end{tabular}

Source: Document of Labschool Unesa Junior High School and Kemala Bhayangkari 1 Junior High School Surabaya in $2018 / 2019$.

From the table above, it can be seen that a decrease in the number of new students enrolled in Labschool Unesa Junior High School and Kemala Bhayangkari 1 Junior High School Surabaya. All because of the new regulations that apply. Apart from competing with public schools, competition with other private schools is also inevitable. Various kinds of strategies need to be done to attract students' interest. Strategy is a unified plan that leads to the achievement of organizational goals, Glueck and Jauch (Abdurrahman, 2015: 197). Strategies need to be done in order to anticipate the rapid competition between schools, determine the direction and goals of the organization clearly, clarify the duties and obligations of the various parties involved in organizational goals so that it is easier and minimizes risk.

Facing such tough competition, one of the strategies that needs to be done is through marketing (marketing). This needs to be done with careful planning so that the expected goals can be achieved. One of the elements in an integrated marketing strategy is the marketing mix strategy. The strategy that is carried out is related to determining how the company presents product offerings in certain segments. At this stage, the marketing mix element is used, which is a combination of variables from the core of the marketing system. Of course, these variables can be controlled by the company to influence consumer reactions. Thus, the marketing mix consists of a set of variables that can be controlled by the company to influence consumer responses in its target market. Strategies that can be done are product strategy, price strategy, distribution strategy and promotion strategy (Huda, 2019:12).

The marketing orientation of schools in this case is not limited to commercializing education for profit, but rather on improving quality in accordance with the demands, expectations and satisfaction of the community (customers). The essence of marketing is to focus on meeting the needs and satisfaction of consumers (Chapman, 1986) considering that marketing is a new method to advance and develop the potential of an organization by focusing targets, especially on the needs of society. If the reality is more than expected, the service can be said of quality. (Mursidi and Sudirman, 2014:29). A school needs to pay attention to its marketing management because it will determine how many students will enroll in the school. However, in education marketing that must be considered not only outside of school, such as the installation of banners or distributing brochures, but there must also be improvements from within the school, especially in improving its resources. Because with the existence of quality resources, it will give birth to a good image in the eyes of the community. (Munir, 2018). The education/school service marketing 
function itself is part of a marketing technique that aims to achieve better results compared to marketing techniques that cannot achieve the target number of students or the desired users of educational services. (Mantja, 2002).

Based on a preliminary study conducted at Labschool Unesa Junior High School, the problem faced by this school is that the school has not been able to determine the right marketing strategy in attracting students' interest. Another problem that arises is that brochures as a school promotion tool are not well distributed. In addition, schools do not have sufficient budgets for the needs of implementing marketing programs. According to (Margareta et al, 2018) school marketing strategies must create good energy for the school environment.Even though this school has advantages including fairly complete school facilities, professional teaching staff and educational staff according to their fields and has a direct development team from the Surabaya State University. As for the Kemala Bhayangkari 1 Junior High School in Surabaya, the problem that arises is a decrease in the number of students because the promotion is not optimal. Brochures as a promotional tool are also poorly distributed. The large number of competing schools also resulted in a decrease in the number of students. The advantages of this school are the school has complete facilities including air-conditioned classrooms, science and computer laboratories, studio bands, mosques and school health unit (UKS). In addition, the location of this school is strategic and easy to reach by public transportation.

The school must maximize the strategy in marketingin order to attract customer interest. Marketing that is carried out must sell the identity of the school, must not lie with the actual situation of the school. Selling with honesty will be more attraction (Fatkurroji, 2015:7).

\section{Materials And Methods}

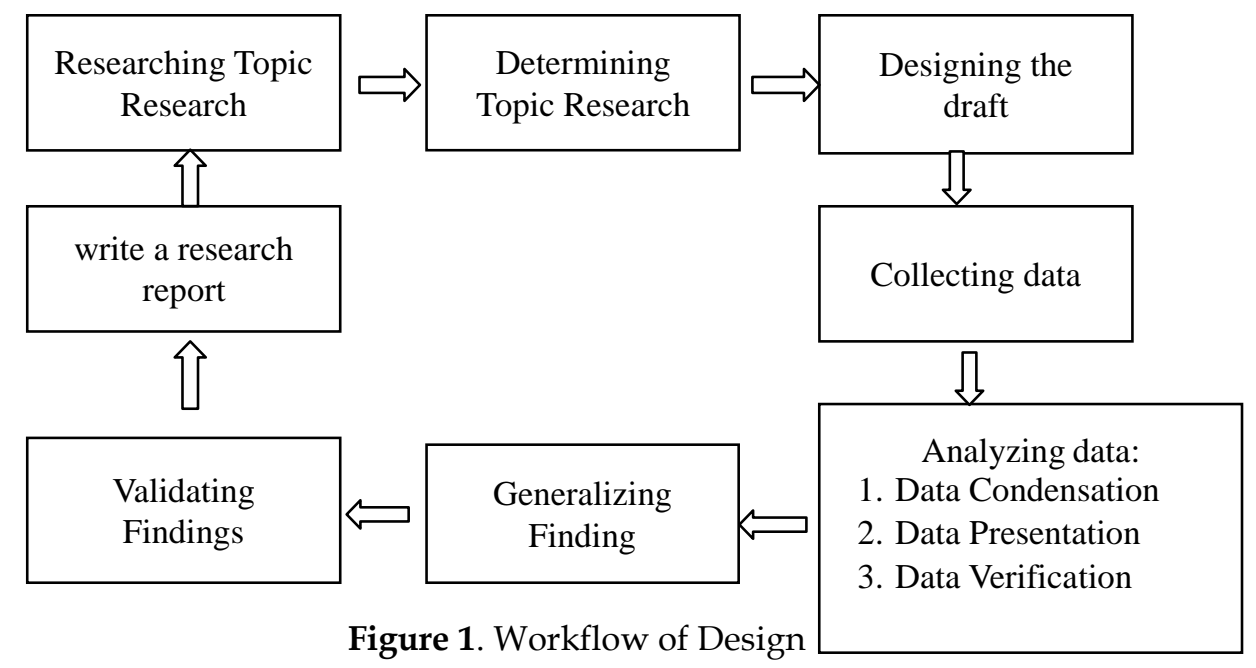

This research uses a case study research type. According to Mulyana (2008: 253) the definition of case study research is an explanation arranged coherently regarding aspects of an individual, group or an institution. Research using this type of case study will reveal the existing phenomena by collecting and using as much data as possible about the thing under study. Researchers used this type of case study because they wanted to investigate and uncover cases related to the themes used in Labschool UNESA Junior High School and Kemala Bhayangkari 1 Junior High School Surabaya. Effectively then present it systematically. Researchers choose the case study approach because the case study approach has very little effect on controlling an existing event, so that the data that is then presented is purely a process and requires in-depth observation.

The stages of the case studies used by the researcher are in accordance with the case study stages described by Ulfatin (2015) as follows (1) selecting and selecting the topic of marketing strategies for Private Junior High Schools in order to address the policy of admission of new students in Public Junior High Schools related to the world education, especially in human relations management, (2) determining problems and topics: marketing strategies carried out by Labschool Junior High School and Kemala Bayangkari Junior High School in order to face the policy of admitting new students at State Junior High Schools (3) designing designs using qualitative research with the case study method, (4) collecting data using observation, interview and documentation techniques, (5) data analysis used in this research is data condensation, data presentation, and data display, (6) generalizing findings by grouping data according to 
the focus of the research after that a conclusion is drawn, (7) validation of the findings is used to check the validity of the data, (8) the last stage is writing a research report.

This research was conducted in the 2020/2021 school year. Data collection techniques using observation, interviews, and documentation. The data analysis technique used in this study was an interactive analysis model consisting of three components: data condensation, data triangulation, data presentation and make a conclusion.

\section{Results And Discussions}

3.1 Strategy in UNESA Labschool Junior High School and Kemala Bhayangkari 1 Surabaya Junior High School in Responding to the Policy for Admission of Public Junior High School Students in Surabaya

UNESA Labschool Junior High School and Kemala Bhayangkari 1 Junior High School have their respective marketing strategies. The marketing strategy is designed in accordance with the school's vision and mission. In line with that, the most important marketing strategy in attracting wider public interest is to carry out promotions. To respond to the new rules of the Surabaya City Education Office regarding the admission of new Public School students, the two schools maximized their promotion through various means. Sutojo (1998: 178) explains that in educational institutions, promotion can be done through mass communication media, for example; newspapers, magazines, television, radio, billboards, and pamphlets. In addition, promotion can also be carried out by supporting promotional activities, namely school / education fairs. According to (Tyagita, 2016) marketing management will run well by establishing good relationships with various junior high schools in various regions, establishing good relationships with alumni, parents and the surrounding community. Exhibition is one example of marketing promotion activity, because in the exhibition various kinds of pictures, billboards, and samples of institution products are installed. Apart from the mass media, the tools used to promote a service product can be in the form of interpersonal methods such as publicity, advocacy, lobbying, educational programs. Even "word of mouth" methods such as rumors, gossip, opinion are also often used.

a. Marketing Strategy in UNESA Labschool Junior High School

1. Excellent programs that can attract the interest of the wider community are: a) Duha prayer together, b) character enhancement program, c) mandatory smile and greetings, d) literacy program and e) compulsory reading before learning.

2. The marketing strategy implemented at UNESA Labschool Junior High School has the following stages: a) forming a marketing team and a New Student Admissions team (PPDB), b) carrying out analysis or observation of developments and community needs, c) making brochures, pamphlets , billboards, advertisements in print and internet media, d) disseminating promotional media, e) opening online and offline registrations according to community needs.

3. In addition to the normal strategy which is always implemented every year, UNESA Labschool Junior High School also has a marketing strategy that is continuously implemented. Namely participating in various competitions on the national and international level. As well as holding a competition held at UNESA Labschool Junior High School for Elementary Schools in Surabaya. This good step aims to make the good name of the school widely known and attract public interest.

4. Maximizing the use of technology in the system used to be more transparent and gain the trust of the public.

5. Complete facilities and infrastructure as well as having teaching and educational staff in accordance with the field. Most of the teaching and education staff are alumni of the Surabaya State University.

b. Marketing Strategy in Kemala Bhayangkari 1 Surabaya Junior High School

1. Kemala Bayangkari 1 Surabaya Junior High School is famous for its disciplinary program, is a scout which has often won several competitions. In addition to the disciplines that are considered, Kemala Bhayangkari 1 Surabaya Junior High School gives special attention to religious programs. Excellent programs that can attract public interest are: a) Al-Quran memorization program, b) Read Al-Quran 10 minutes before the lesson starts, c) Friday spiritual for non-Muslim students.

2. The marketing strategy in Kemala Bhayangkari 1 Surabaya Junior High School has the following stages: a) creating a new student admissions team consisting of teachers and staff, the team will change personnel every year to increase the experience and abilities of teachers and staff in terms of school marketing, b) making New Student Admissions Decrees that must be complied with, c) holding meetings to discuss last year's marketing evaluation and marketing strategies to be 
implemented, analyzing community dynamics and important educational needs, d) designing educational marketing media such as brochures, leaflets, billboards, banners, and online advertisements, e) opening offline and online registrations as needed.

3. Apart from utilizing the internet as online marketing, Kemala Bhayangkari 1 Junior High School also carries out promotions on local TV in Surabaya.

4. Facilities and infrastructure that are fully supported by the East Java Kemala Bhayangkari Association will be a special attraction for the community.

3.2 Internal Factors of Marketing Strategy in UNESA Labschool Junior High School and Kemala Bhayangkari 1 Surabaya Junior High School

a. Internal Factors of Marketing Strategy in UNESA Labschool Junior High School

1. The strengths of the school that can support the running of the marketing strategy properly are: a) having a big name Surabaya State University, b) a strategic location on the UNESA Ketintang campus, c) having human resources that support the running of the school program, d) a system that is have switched from manual to technology-based, e) have a character enhancement program which is the main attraction.

2. The marketing strategy that is implemented will not go according to plan if the school does not know the weaknesses that exist within itself, the weaknesses of schools in UNESA Labschool Junior High School which can hinder the marketing strategy is that it is still difficult to find characteristics compared to Labschool UNESA Junior High School in Lidah Wetan.

3. Educators and education staff who are at very important of UNESA Labschool Junior High School have a solid and unified collaboration, and participate in educational training in accordance with their fields to improve teaching and managerial skills.

b. Internal Factors of Marketing Strategy in Kemala Bhayangkari 1 Surabaya Junior High School

1. The existing marketing strategy at Kemala Bhayangkari 1 Surabaya Junior High School has had a positive impact so far, with the sufficient number of study groups opened. The strengths of the school that support the implementation of the marketing strategy are: a) strategic location on the main road between cities, b) guaranteed entry to the Kemala Bhayangkari High School for alumni, known for its characteristics with high discipline.

2. Weaknesses that must be minimized in implementing marketing strategies are the need for human resource capabilities in terms of technology and information. So that the human resources concerned can be given training or guidance so that they can go hand in hand with others as a system.

3. The policies and programs implemented will depend on the incumbent leadership. Likewise, Kemala Bhayangkari 1 Junior High School Surabaya, policies and programs follow the incumbent Mrs. Bhayangkari. In changing periods, policies and programs can be added or revised according to conditions.

3.3 Eksternal Factors of Marketing Strategy in UNESA Labschool Junior High School and Kemala Bhayangkari 1 Surabaya Junior High School

a. Eksternal Factors of Marketing Strategy in UNESA Labschool Junior High School

1. Being under a foundation which is directly managed by UNESA, makes Labschool Junior High School a profitable opportunity. The opportunity to be directly guided by experts who are experienced in education will make it easier for resources to be upgraded.

2. There is a threat that affects marketing in UNESA Labschool Junior High School, namely the number of public schools in the same area. So that the community standard will be higher in choosing a school.

3. Technological conditions, changing societal dynamics, and political conditions also have an indirect impact on the school's marketing strategy. Especially the public's interest and perception in choosing a school.

b. External Factors of Marketing Strategy in Kemala Bhayangkari 1 Surabaya Junior High School

1. Many public and private schools in the school area.

2. Government policy regarding the zone system which requires students to go to school near home.

3. The current social, cultural and political situation. 


\section{Conclusion}

There are several similarities and differences in the marketing strategies that exist in the two schools. The similarities are the characteristics of the flagship program related to religious programs which are currently in great demand by prospective students and prospective student guardians in choosing schools, as well as the steps in marketing strategies that are not much different. The difference lies in the way to form a New Student Admissions team or school marketing team, UNESA Labschool Junior High School always forms a team of experienced people. Meanwhile, Kemala Bhayangkari 1 Junior High School Surabaya formed a team with alternating members so that all have the ability to market the school and master the strengths that must be highlighted. The promotional media from both schools have a unique and attractive design and are easy to understand. By including together the vision and mission, superior programs and procedures for registering. The marketing strategy of the two schools in order to overcome the new policies of the Surabaya City Education Office has gone well and is in accordance with the wishes of the institution. Educational goals have also been achieved and the most important thing is that education customer satisfaction has been met.

\section{References}

Abdurahman. (2012). Madrasah dan Pendidikan Anak bangsa: Visi, Misi dan Aksi. Bandung: PT Remaja Rosdakarya

Alma, B. (2009). Pemasaran Stratejik Jasa Pendidikan. Bandung: Alfabeta

Alma dan Hurriyati. (2008). Manajemen Corporate \& Strategi Pemasaran Jasa Pendidikan: Fokus pada Mutu dan Layanan Prima. Bandung: Alfabeta.

Amstrong, Gary dan kotler, Philip. (2012) Prinsip-prinsip Pemasaran. Jakarta: Erlangga

Azra, Azyumardi. 1999. Pendidikan Islam : Tradisi dan Modernisasi menuju melenium baru, Penerbit Logos Wacana ilmu, Jakarta

Buchari Alma dan Ratih Hurriyati. (2008). Manajemen Corporate dan Strategi Pemasaran Jasa Pendidikan Fokus Pada Mutu dan Layanan Prima. Bandung: Alfabeta

Bulley, Cynthia A. (2014). Strategic Marketing In Education Services The Case Of Private Tertiary Institution In Ghana. Journal Of Economics, Commerce and Management. Vol II, Issue.

David, Wijaya. (2008). Pemasaran Jasa Pendidikan sebagai Upaya untuk Meningkatkan Daya Saing Sekolah, Jurnal Pendidikan Penambur, No. 11 Tahun ke 7

Fatkurroji. (2015). Desain Model Manajemen Pemasaran Berbasis Layanan Jasa Pendidikan pada. mts Swasta Se-Kota Semarang. Nadwa: Jurnal Pendidikan Islam. Vol (9), 1

Hastuti, Sri M. (2007). Perkembangan Menarik Dalam Pemasaran Jasa. Jurnal Ilmiah Manajemen Bisnis,7(3) 169.

Huda. (2019). Manajemen Pemasaran Sekolah. Ta'dibi: Jurnal Manajemen Pendidikan Islam. Vol (8) 01.

Kotler, Philip. (2000). Manajemen Pemasaran. Jilid 2. Jakarta: Bumi Aksara

Kotler, Philip. (2005). Manajemen Pemasaran, Jilid 1 dan 2. Jakarta: PT. Indeks Kelompok Gramedia

Kotler, P dan Susanto, A, B. (1999). Manajemen Pemasaran di Indonesia. Jakarta: Salemba Empat

Kalenskaya, N.V. (2015). Marketing Strategiy Of Higher Education Institutions. Journal Of Sciences MCSER Publishing. Vol 6 No 1.

Lestari, S. (2011). Strategi Pemasaran Sekolah di SMA 1 Batik Surakarta (Doctoral dissertation, Universitas Muhammadiyah Surakarta

Mantja, Willem. (2002). Manajemen Pendidikan Dan Supervisi Pengajaran. Malang: Wineka Media

Margareta, Ririn T., Ismanto Bambang dan Sulasmono Bambang. (2018). Strategi Pemasaran Sekolah Dalam Meningkatkan Minat Peserta Didik Berdasarkan Delta Model. Jurnal Manajemen Pendidikan. Vol 5

Miles dan Huberman. (1992). Analisis Data Kualitatif. Alih Bahasa: Rohidi, TR. Jakarta: Universitas Indonesia

Moleong, Lexi J. (2010). Metodologi Penelitian Kualitatif. Bandung: PT. Remaja Rosdakarya

Mulyasa, Enco. (2004). Manajemen Berbasis Sekolah. Bandung: PT. Remaja Rosdakarya

Munir, M. (2018). Manajemen Pemasaran Pendidikan dalam Meningkatkan Kualitas Peserta Didik. Jurnal Manajemen Pendidikan Islam, Vol (1) 2

Mursidi, et al. (2014). "Phenomenon on the Level of Lecturer Education, in Quality of Education and Quality of Graduates." International Proceedings of Economics Development and Research (81) 29

Permendikbud. (2018). Peraturan Menteri Pendidikan dan Kebudayaan Republik Indonesia Nomor 14 Tahun 2018 tentang Penerimaan Peserta Didik Baru pada Taman Kanak-kanak, Sekolah Dasar, Sekolah Menengah Pertama, Sekolah Menengah Atas, Sekolah Menengah Kejuruan, atau Bentuk Lain yang Sederajat. Jakarta: Kepala Biro Hukum dan Organisasi Kementerian Pendidikan dan Kebudayaan

Petunjuk Teknis Penerimaan Peserta Didik Baru SMP/MTs dan SLB Negeri Tahun Pelajaran 2018/2019 
Sugiyono. (2013). Metode Penelitian Kuantitatif, Kualitatif, dan RED. Bandung: Alfabeta

Tilaar, H.A.R. (2001). Manajemen Pendidikan Nasional. Bandung: Remaja Rosdakarya

Tyagita, Brigitta. (2016). Strategi Pemasaran Sekolah Menengah Atas Swasta Berasrama di Kabupaten Semarang. Jurnal Manajemen Pendidikan Vol (3) 1

Ulfatin, Nurul. (2015). Metode penelitian kualitatif di bidang pendidikan: teori dan aplikasinya- studi kasus, etnografi, interaksi simbolik dan penelitian tindakan pada konteks manajemen pendidikan. Malang: Media Nusa Creative.

Vanhamme, J, Palmer, R, Lindgreen, A. Contemporary Marketing Practice: Theoritical Propositions and Practical Implications. Journal Of Marketing Intelligence and Planning. 22(6) 673-692.

Wijaya, D. (2012). Pemasaran Jasa Pendidikan. Jakarta: Penerbit Salemba Empat.

Wright, Christine, and Martin O'Neill. "Service Quality Evaluation in the Higher Education Sector: An Empirical Investigation of Students' Perceptions." Higher Education Research \& Development 21, no. 1 (2002): 23-39.

Yeti, H.,dan Muhsin, M. (2014). Manajemen Sumber Daya Pendidikan. Bandung: CV Pustaka Setia 